\title{
High prevalence of multidrug resistance in bacterial uropathogens from Kathmandu, Nepal
}

\author{
Pankaj Baral ${ }^{1,2^{*}}$, Sanjiv Neupane ${ }^{1 \dagger}$, Bishnu Prasad Marasini ${ }^{1}$, Kashi Ram Ghimire ${ }^{1}$, Binod Lekhak ${ }^{1}$ and \\ Basudha Shrestha ${ }^{3}$
}

\begin{abstract}
Background: Urinary Tract Infection (UTI) is one of the most common infectious diseases and people of all agegroups and geographical locations are affected. The impact of disease is even worst in low-resource developing countries due to unaware of the UTIs caused by multidrug-resistant (MDR) pathogens and the possibility of transfer of MDR traits between them. The present study aimed to determine the prevalence of MDR bacterial isolates from UTI patients, the antibiotic resistance pattern and the conjugational transfer of multidrug resistance phenotypes in Escherichia coli (E. coli).

Results: Two hundred and nineteen bacterial isolates were recovered from 710 urine samples at Kathmandu Model hospital during the study period. All samples and isolates were investigated by standard laboratory procedures. Among the significant bacterial growth (30.8\%, 219 isolates), $41.1 \%$ isolates were MDR. The most prevailing organism, E. coli (81.3\%, 178 isolates) was 38.2\% MDR, whereas second most common organism, Citrobacter spp. (5\%, 11 isolates) was found 72.7\% MDR. Extended-spectrum $\beta$-lactamase (ESBL) production was detected in $55.2 \%$ of a subset of MDR E. coli isolates. Among the 29 MDR E. coli isolates, plasmids of size ranging 2-51 kb were obtained with different 15 profiles. The most common plasmid of size $32 \mathrm{~kb}$ was detected in all of the plasmid-harbored E. coli strains. The majority of E. coli isolates investigated for the multidrug resistance transfer were able to transfer plasmid-mediated MDR phenotypes along with ESBL pattern with a frequency ranging from $0.3 \times 10^{-7}$ to $1.5 \times 10^{-7}$ to an E. coli HB101 recipient strain by conjugation. Most of the donor and recipient strain showed high levels of minimum inhibitory concentration (MIC) values for commonly-used antibiotics.

Conclusions: The high prevalence of multidrug resistance in bacterial uropathogens was observed. Particularly, resistance patterns were alarmingly higher for amoxycillin, co-trimoxazole, flouroquinolones and third-generation cephalosporins, which necessitate the re-evaluation of first and second line therapies for UTI. In addition, conjugational co-transfer of MDR phenotypes with ESBL-positive phenotypes was observed in MDR E. coli.
\end{abstract}

Keywords: Urinary tract infection, Multidrug resistance, Plasmid

\section{Background}

Urinary tract infection is a common bacterial disease, often contributes to a frequent cause of morbidity in out-patients as well as hospitalized-patients [1]. Clinical experience has indicated the presence of numerous cases of antibiotic resistance to common antibiotics by uropathogens in both developed and developing countries [2]. Resistant to newer and more potent

\footnotetext{
* Correspondence: pankaj.baral@gmail.com

† Contributed equally

${ }^{1}$ Central Department of Microbiology, Tribhuvan University, Kirtipur,

Kathmandu, Nepal

Full list of author information is available at the end of the article
}

antimicrobials are no exceptions, making the therapeutic options very limited to certain antimicrobial agents like carbapenem, colistin and fosfomycin [3]. In many parts of Nepal, the facilities for urine culture and antimicrobial susceptibility testing are still not available, leading to improper diagnosis and irrational antibiotic treatment (e.g. self-medication) of UTI [4]. The updated knowledge and situation of the prevailing bacterial uropathogens that are multidrug resistant (MDR) is of prime importance for the proper use of antimicrobial drugs and the policy making to combat multidrug resistance in UTIs [3].

\section{Biomed Central}

(c) 2012 Baral et al; licensee BioMed Central Ltd. This is an Open Access article distributed under the terms of the Creative Commons Attribution License (http://creativecommons.org/licenses/by/2.0), which permits unrestricted use, distribution, and reproduction in any medium, provided the original work is properly cited. 
Invariably, Escherichia coli (E. coli) has been found as a most common uropathogen in a number of reports worldwide [5-7]. Antimicrobial therapy of UTI caused by $E$. coli is often impaired due to the resistance to commonly-used antimicrobial agents [3,5]. Although E. coli has been reported to be MDR by possessing the antibiotic resistant genes in its transferable R-plasmid (s) [8], detection of this feature in UTI isolates from Nepal is largely unknown. The present study aimed to determine the prevalence of MDR bacterial isolates in UTI, the antibiotic resistance pattern, the plasmid profile of isolated MDR $E$. coli, and the transfer of multidrug resistance phenotypes by conjugation. Our data might be informative to both of the health professionals and the scientific community, which may help to make a positive contribution to current understanding and knowledge of the situation in UTI caused by MDR bacterial pathogens.

\section{Methods}

\section{Study population and bacterial isolates}

This prospective study was carried out at Kathmandu Model Hospital between 1st May and 30th September 2007. This public hospital is one of big hospitals located in capital, Kathmandu, where patients across the country visit regularly. Conduction of this study was approved by ethics and research committee of Kathmandu Model Hospital. Written informed consents were obtained from all cases prior to their inclusion in the study. All suspected patients of UTI during the study period were interviewed directly with structured questionnaire to collect data about patient's demographics, type of patient (hospitalized- or out-patient), symptoms, prior history of UTI, and underlying diseases. Only those cases with at least one of the clinical features of UTI (dysuria, frequency, urgency, loin pain or prior history of UTI) were judged as clinically-suspected patients of UTI and selected for confirmation of UTI. A total of 710 midstream 'clean-catched' urine samples were collected from the same number of clinically-suspected patients of UTI. Once the sample was collected, transferred to the laboratory immediately and inoculated on blood agar and McConkey agar using a standard calibrated loop. Isolates from cases with significant bacteriuria $\left(10^{5}\right.$ colonies $\left./ \mathrm{ml}\right)$ were identified based upon standard laboratory procedures involving, morphological characteristics, Gram's stain, rapid tests (catalase, oxidase, coagulase, bile solubility), and biochemical tests (IMViC [Indole, methyl red, Voges-Proskauer and citrate], TSI [triple sugar iron], O/F [oxidation/fermentation], urease and nitrate reduction) [9]. Single isolate was selected from each of diagnosed samples. UTI diagnosis was established on the basis of pyuria ( $\geq 5$ leukocytes per high-power field on microscopic examination of the urine), clinical feature (s) (as mentioned above) and significant bacteriuria.

\section{Antimicrobial susceptibility testing and MIC testing}

Antimicrobial susceptibility patterns were determined according to the Clinical and Laboratory Standards Institute (CLSI)-recommended modified Kirby-Bauer disc diffusion method on Mueller-Hinton agar with commercial antibiotic discs (Oxoid Ltd, UK) [10]. Susceptibility to eight antimicrobial agents (amoxycillin, cefotaxime, cefixime, ciprofloxacin, cotrimoxazole, nitrofurantoin, norfloxacin and ofloxacin; used as primary) was determined for 209 g- negative bacterial isolates. Of these, 56 isolates were tested by additional antibiotic discs (amikacin, chloramphenicol, ceftazidime, ceftriaxone and gentamycin; used as secondary). Susceptibility to seven antimicrobial agents (amoxycillin, cephalexin, ciprofloxacin, cotrimoxazole, cloxacillin, erythromycin and norfloxacin) was determined for all 10 g- positive isolates. Four of these isolates were also tested by an additional antibiotic disc (vancomycin). Antibiotic concentrations in the diffusion discs used for antimicrobial susceptibility testing are: amikacin $(30 \mu \mathrm{g})$, amoxycillin $(10 \mu \mathrm{g})$, cefixime $(5 \mu \mathrm{g})$, cefotaxime $(30 \mu \mathrm{g})$, ceftazidime $(30 \mu \mathrm{g})$, ceftriaxone $(30 \mu \mathrm{g})$, cephalexin $(30 \mu \mathrm{g})$, chloramphenicol $(30 \mu \mathrm{g})$, ciprofloxacin $(5 \mu \mathrm{g})$, cloxacillin $(5$ $\mu \mathrm{g})$, co-trimoxazole $(1.25 / 23.75 \mu \mathrm{g})$, erythromycin $(15$ $\mu \mathrm{g})$, gentamycin $(10 \mu \mathrm{g})$, nitrofurantoin $(300 \mu \mathrm{g})$, norfloxacin $(10 \mu \mathrm{g})$, ofloxacin $(5 \mu \mathrm{g})$ and vancomycin (30 $\mu \mathrm{g}$ ). Escherichia coli (ATCC 25922) and Staphylococcus aureus (ATCC 25923) were used as controls for Gramnegative and Gram positive bacteria, respectively.

Those organisms which showed resistance to at least three or more antibiotics of different structural classes were considered MDR as described elsewhere [11,12]. MDR E. coli isolates were preserved in tyrptic soy broth containing $20 \%$ glycerol at $-70^{\circ} \mathrm{C}$ until further investigation.

Minimum inhibitory concentration (MIC) for donors and transconjugants was determined by two fold broth macrodilution method as recommended by CLSI [13]. The inocula of $4 \times 10^{5}$ colony forming unit (CFU) were prepared from suitably diluted overnight broth culture at $37^{\circ} \mathrm{C}$. Positive growth controls were kept for each isolates and E. coli 25922 of known MIC was also included in each test as control for antibiotic potency. MIC was defined as the minimum concentration of antimicrobial agent that prevented the visible growth of bacteria. The range of antibiotic concentrations employed in MIC test is: ampicillin (1-512 $\mu \mathrm{g} / \mathrm{ml})$, ciprofloxacin $(0.016-256 \mu \mathrm{g} / \mathrm{ml})$, cefixime (1-512 $\mu \mathrm{g} / \mathrm{ml})$, chloramphenicol (1-512 $\mu \mathrm{g} / \mathrm{ml})$, norfloxacin $(0.016-256 \mu \mathrm{g} / \mathrm{ml})$, co-trimoxazole $(1-512 \mu \mathrm{g} / \mathrm{ml})$ and gentamycin $(0.5-64 \mu \mathrm{g} / \mathrm{ml})$. The antibiotic powders were provided by National Drug Laboratory, Kathmandu, Nepal

\section{Determination of ESBL production}

The ESBL-producing phenotypes from the 29 MDR E. coli isolates were determined by Kirby-Bauer disc 
diffusion method following CLSI recommendation. Amoxy-clavulanic acid $(20 / 10 \mu \mathrm{g})$ disc (Oxoid Ltd, UK) was placed in the center of ceftazidime $(30 \mu \mathrm{g})$ and cefotaxime $(30 \mu \mathrm{g})$ discs with $25-30 \mathrm{~mm}$ apart. After overnight incubation at $37^{\circ} \mathrm{C}$ in air, confirmation of ESBL-producing organism was assessed when the zone of inhibition around ceftazidime and cefotaxime was expanded by at least $5 \mathrm{~mm}$ by the presence of clavulanic acid [14]. E. coli ATCC 25922 and Klebsiella pneumoniae ATCC 700603 were used as negative and positive controls for ESBL production, respectively.

\section{Plasmid profiles and conjugation}

Plasmid DNA from MDR E. coli was extracted from the overnight culture (mid log phase) grown in Lauria-Bertani (LB) broth supplemented with antibiotic $(100 \mu \mathrm{g} / \mathrm{ml}$ of ampicillin). The plasmid DNA was extracted and purified using a QIAprep spin miniprep kit (Qiagen, Germany) according to the manufacturer's instruction. Considering that the isolation of large plasmid may be affected using miniprep, isolation was carried out additional two times for those large plasmid ( $>20 \mathrm{~kb}$ ) to be ensured about the proper plasmid size and number in the isolates. The plasmid DNA was analyzed through $0.5 \%$ horizontal agarose gel electrophoresis. Electrophoresis was run at $0.6 \mathrm{Vcm}^{-2}$ for $4 \mathrm{~h}$ in TAE buffer $(40 \mathrm{mM}$ Tris-acetate, $1 \mathrm{mM}$ EDTA). Reference supercoiled plasmid DNA marker (New England Biolab, England) and plasmid from E. coli V517 were used for the estimation of plasmid sizes.

The MDR E. coli strains showing sensitivity to streptomycin were selected for conjugation study, serving as donors. The plasmid-free, streptomycin-resistant strain of $E$. coli (E. coli HB 101), showing sensitivity to all antibiotics under study, was used as a recipient. Conjugation was carried out as similarly described elsewhere [8]. Briefly, all donor E. coli strains and recipient E. coli strain were grown with antibiotic supplement till the $\mathrm{O}$. D. of each type reaches 0.85 at $\mathrm{A}_{600}$ (approximately $10^{8}$ cells $/ \mathrm{ml}$ ). Each of $0.2 \mathrm{ml}$ donor and recipient culture broth were mixed together in $2.5 \mathrm{ml}$ warm LB broth and incubated at $37^{\circ} \mathrm{C}$ without shaking. After $24 \mathrm{~h}$. of incubation, bacteria were then plated onto selective LB agar supplemented with streptomycin $(100 \mu \mathrm{g} / \mathrm{ml})$ and at least one of the following antibiotics: ampicillin (30 $\mu \mathrm{g} / \mathrm{ml})$, ciprofloxacin $(0.045 \mu \mathrm{g} / \mathrm{ml})$, cefixime $(2 \mu \mathrm{g} / \mathrm{ml})$, chloramphenicol $(20 \mu \mathrm{g} / \mathrm{ml})$, norfloxacin $(0.3 \mu \mathrm{g} / \mathrm{ml})$, trimethoprim $(200 \mu \mathrm{g} / \mathrm{ml})$, cefotaxime $(2 \mu \mathrm{g} / \mathrm{ml})$ and gentamycin $(10 \mu \mathrm{g} / \mathrm{ml})$. It should be noted that the indicated concentrations of above antibiotics inhibited the growth of recipient strain E. coli HB101 only, but not donors. The transconjugants were identified based upon the visible growth on these counter-antibiotic containing medium and subjected for plasmid profiling. To ensure the transconjugants selection only by conjugation, not by mutation that can alter the streptomycin susceptibility in the donor strains, controls (for donor and recipient strain) were run in each conjugation experiment parallely, involving similar procedure of conjugation, but without adding recipient culture broth (for donor control) and donor culture broth (for recipient control). Successful conjugation was ascertained by finding no growth from controls, while visible growth from the conjugation mixture bacteria, in LB agar supplemented with streptomycin and at least one of aforementioned antibiotics. The antibiogram of the donors and transconjugants were studied by disc diffusion method and MIC testing as described above.

\section{Statistical analysis}

The data was analyzed by using Minitab version 15 (Minitab Inc., USA). Statistical tests of significance were performed using the Kruskall-Wallis test. A $p$ value of $\leq$ 0.05 was considered significant.

\section{Results}

\section{Bacterial uropathogens}

Two-hundred and nineteen bacterial pathogens (30.8\%) were isolated from the 710 clinically-suspected cases of UTIs. High incidences of UTI cases were observed, among female patients $(33.5 \%, 173 / 516)$ than male patients $(23.7 \%, 46 / 194)(p<0.05)$, and in hospitalizedpatients $(51.3 \%, 20 / 39)$ than out-patients $(29.7 \%, 199 /$ 671) $(p<0.05)$. Out of the 219 isolates, Gram-negative bacilli accounted for $95.4 \%$ while Gram-positive cocci accounted for the remaining $4.6 \%$ of the total isolates. The most common urinary pathogen isolated was $E$. coIi (81.3\%), followed by Citrobacter spp. (5\%) and coagulase-negative staphylococci (CoNS) [2.7\%; S. epidermidis $(1.8 \%)$ and S. saprophyticus $(0.9 \%)$ ] (Table 1$)$. The percent resistance to antibiotics shown by the Gram-negative pathogens are shown in Table 2. E. coli showed the high resistance rate against most of the primary drugs tested: amoxycillin (55.6\%), co-trimoxazole $(54.4 \%)$, norfloxacin (36.5\%), ciprofloxacin (35.9\%) and cefixime (30.3\%). Comparatively, it showed low resistance rate against a primary drug, nitrofurantoin (7.9\%). Out of the 13 antibiotics tested for E. coli isolates, the least resistance was observed to amikacin (6.2\%) (Table 2).

The most predominant Gram-positive isolates, CoNS, showed a least resistance ( $16.7 \%$ in each) against the primary antibiotics (amoxycillin, ciprofloxacin, erythromycin and norfloxacin).

\section{Multidrug resistance in bacterial uropathogens}

Out of the 219 isolates, $41.1 \%$ were MDR according to the mentioned criteria. High incidence of UTIs caused by MDR pathogens was observed, among male patients 
Table 1 Distribution of MDR bacterial uropathogens

\begin{tabular}{|c|c|c|c|c|c|c|}
\hline \multirow[t]{2}{*}{ Organism } & \multicolumn{2}{|c|}{ In hospitalized-patient } & \multicolumn{2}{|c|}{ In out-patient } & \multicolumn{2}{|c|}{ Total } \\
\hline & $\begin{array}{c}\text { No of isolates } \\
(\%)\end{array}$ & $\begin{array}{c}\text { No of MDR isolates } \\
(\%)\end{array}$ & $\begin{array}{c}\text { No of isolates } \\
(\%)\end{array}$ & $\begin{array}{c}\text { No of MDR isolates } \\
(\%)\end{array}$ & $\begin{array}{c}\text { No of isolates (\% of } \\
\text { total) }\end{array}$ & $\begin{array}{c}\text { No of MDR isolates } \\
(\%)\end{array}$ \\
\hline Acinetobacter spp. & 1 & $1(100)$ & 1 & $0(0)$ & $2(0.9)$ & $1(50)$ \\
\hline Citrobacter spp. & 5 & $5(100)$ & 6 & $3(50)$ & $11(5)$ & $8(72.7)$ \\
\hline Enterobacter spp. & 0 & $0(0)$ & 4 & $1(25)$ & $4(1.8)$ & $1(25)$ \\
\hline Escherichia coli & 11 & $8(72.7)$ & 167 & $60(35.9)$ & $178(81.3)$ & $68(38.2)$ \\
\hline Klebsiella oxytoca & 0 & $0(0)$ & 2 & $1(50)$ & $2(0.9)$ & $1(50)$ \\
\hline K. pneumoniae & 0 & $0(0)$ & 4 & $1(25)$ & $4(1.8)$ & $1(25)$ \\
\hline Morganella morganii & 0 & $0(0)$ & 2 & $0(0)$ & $2(0.9)$ & $0(0)$ \\
\hline Proteus mirabilis & 0 & $0(0)$ & 3 & $0(0)$ & $3(1.4)$ & $0(0)$ \\
\hline $\begin{array}{l}\text { Pseudomonas } \\
\text { aeruginosa }\end{array}$ & 0 & $0(0)$ & 2 & $2(100)$ & $2(0.9)$ & $2(100)$ \\
\hline Salmonella typhi & 1 & $1(100)$ & 0 & $0(0)$ & $1(0.5)$ & $1(100)$ \\
\hline $\begin{array}{l}\text { Staphylococcus } \\
\text { aureus }\end{array}$ & 0 & $0(0)$ & 1 & $1(100)$ & $1(0.5)$ & $1(100)$ \\
\hline CoNS* & 1 & $1(100)$ & 5 & $2(40)$ & $6(2.7)$ & $3(50)$ \\
\hline Enterococcus faecalis & 1 & $1(100)$ & 2 & $2(100)$ & $3(1.4)$ & $3(100)$ \\
\hline Total & 20 & $17(85)$ & 199 & $73(36.7)$ & $219(100)$ & $90(41.1)$ \\
\hline
\end{tabular}

${ }^{*} \mathrm{CoNS}=$ coagulase-negative staphylococci

$(58.7 \%, 27 / 46)$ than female patients $(36.42 \%, 63 / 173)(p$ $<0.05)$, also in hospitalized-patients $(85 \%, 17 / 20)$ than out-patients $(36.7 \%, 73 / 199)(p<0.05)$. Although multidrug resistance was shown $100 \%$ by Enterococcus faecalis, Salmonella typhi, Staphylococcus aureus and Pseudomonas aeruginosa, these were low in number and considered insignificant. Out of the $178 \mathrm{E}$. coli isolates, $38.2 \%$ were confirmed to be MDR (Table 1). E. coli (75.5\%, 68/90) and Citrobacter spp. (8.9\%, 8/90) shared the major part of MDR isolates (Table 1). The MDR E. coli isolates demonstrated the extended resistance pattern to different classes of antibiotics, such as $7.3 \%$ isolates showed resistance to 5-6 classes (Table 3).

Majority of MDR E. coli isolates showed high resistance to different classes of antibiotics used: co-trimoxazole $(86.8 \%)$, penicillin (amoxycillin, 94.1\%), quinolone (ciprofloxacin and ofloxacin [92.6\% in each]), cephalosporin (cefotaxime [79.4\%] and cefixime [77.9\%]) and nitrofurantoin (17.6\%). Similarly, these MDR isolates were also shown high antibiotic resistance among the secondary antibiotics evaluated e.g. cephalosporin (ceftazidime and ceftriaxone [100\% in each]), aminoglycosides (gentamycin [72.9\%] and amikacin [6.2\%]) and chloramphenicol (27.1\%). The most common three types of multidrug resistance pattern by these MDR E. coli isolates, in respective order, include resistance to: amoxycilin, ciprofloxacin, cephotaxime, cefixime, cotrimoxazole, ofloxacin, norfloxacin, ceftazidime, gentamycin, ceftriaxone; amoxycilin, ciprofloxacin, cephotaxime, cefixime, cotrimoxazole, ofloxacin, norfloxacin, ceftazidime and amoxycilin, ciprofloxacin, cefixime, cotrimoxazole, ofloxacin, norfloxacin, ceftazidime, chloramphenicol, gentamycin, ceftriaxone.

\section{ESBL production, plasmid profiling and multidrug resistance transfer}

Out of the 68 MDR E. coli isolates, 29 isolates representing the most common MDR patterns were further analyzed for ESBL production and plasmid profiling. ESBL production was detected in 16 (55.2\%) isolates. All MDR E. coli isolates that were analyzed for plasmid profiles harbored at least single plasmid. Altogether 15 different types of plasmid profiles of size ranging from 2 to $51 \mathrm{~kb}$ were detected. Of which, 12 isolates showed single plasmid, 3 showed double plasmids, whereas 6, 6, 1 and 1 isolates showed 3, 4, 5, and 7 plasmids, respectively. The most common plasmid of size $32.5 \mathrm{~kb}$ was detected in the majority of the plasmid-harbored MDR E. coli strains. Out of the 29 plasmid-harbored MDR E. coli isolates, 10 isolates were screened and selected for conjugation study. Each of the isolates containing either single or multiple plasmids can transfer single or multiple plasmids to the recipient strain by conjugation. The highest transfer of plasmid of size $51 \mathrm{~kb}$ was detected by conjugation experiment. The MDR pattern (amoxycillin, ciprofloxacin-, cefixime-, cotrimoxazole-, ofloxacin-, and norfloxacin-resistance) was found most likely to be transferred to recipient strain by conjugation with highest conjugation frequency of $1.5 \times 10^{-7}$ (Table 4 ).

Majority of donor strains $(85.7 \%, 6$ isolates) can transfer the ESBL production phenotype to the recipient strain by conjugation (Table 4). Most of the donors and 
Table 2 Number (percent) of Gram-negative urinary pathogens resistant to antimicrobial agents

\begin{tabular}{|c|c|c|c|c|c|c|c|c|c|c|c|}
\hline Antibiotic & $\begin{array}{l}\text { Escherichia } \\
\text { coli }\end{array}$ & $\begin{array}{l}\text { Klebsiella } \\
\text { spp. }\end{array}$ & $\begin{array}{l}\text { Proteus } \\
\text { mirabilis }\end{array}$ & $\begin{array}{l}\text { Pseudomonas } \\
\text { aeruginosa }\end{array}$ & $\begin{array}{l}\text { Enterobacter } \\
\text { spp. }\end{array}$ & $\begin{array}{l}\text { Citrobacter } \\
\text { spp. }\end{array}$ & $\begin{array}{l}\text { Acinetobacter } \\
\text { spp. }\end{array}$ & $\begin{array}{l}\text { Salmonella } \\
\text { typhi }\end{array}$ & $\begin{array}{l}\text { Morganella } \\
\text { morganii }\end{array}$ & $\begin{array}{l}\text { No of re } \\
\text { isolates/ } \\
\text { isolates } \\
\text { resistan }\end{array}$ & tant \\
\hline Amoxycillin(Am) & $99 / 178(55.6)$ & $6 / 6(100)$ & $1 / 3(33.3)$ & NT & NT & $8 / 11(72.7)$ & $1 / 2(50)$ & $1 / 1(100)$ & NT & $116 / 201$ & $(57.7)$ \\
\hline Cefotaxime(Ce) & $54 / 178(30.3)$ & 2/6(33.3) & $0 / 3(0)$ & $1 / 2(50)$ & $1 / 4(25)$ & 7/11(63.6) & $1 / 2(50)$ & $0 / 1(0)$ & $0 / 2(0)$ & $66 / 209$ & (31.6) \\
\hline Ciprofloxacin(Cf) & $64 / 178(35.9)$ & 1/6(16.7) & $0 / 3(0)$ & $1 / 2(50)$ & $0 / 4(0)$ & $6 / 11(54.5)$ & $0 / 2(0)$ & 1/1(100) & $0 / 2(0)$ & 73/209 & (34.9) \\
\hline Cefixime(Cfx) & $54 / 178(30.3)$ & 2/6(33.3) & $0 / 3(0)$ & $2 / 2(100)$ & $1 / 4(25)$ & 8/11(72.7) & $1 / 2(50)$ & $0 / 1(0)$ & $0 / 2(0)$ & $68 / 209$ & (32.5) \\
\hline Cotrimoxazole(Co) & $97 / 178(54.4)$ & 2/6(33.3) & $1 / 3(33.4)$ & $2 / 2(100)$ & $1 / 4(25)$ & $8 / 11(72.7)$ & $1 / 2(50)$ & $0 / 1(0)$ & $0 / 2(0)$ & $112 / 209$ & (53.6) \\
\hline Nitrofurantoin(Nf) & 14/178(7.9) & $4 / 6(66.6)$ & NT & NT & $1 / 4(25)$ & $5 / 11(45.4)$ & $2 / 2(100)$ & $1 / 1(100)$ & NT & $27 / 202$ & (13.4) \\
\hline Norfloxacin(Nx) & $65 / 178(36.5)$ & $1 / 6(16.7)$ & $0 / 3(0)$ & $2 / 2(100)$ & $0 / 4(0)$ & $6 / 11(54.5)$ & $1 / 2(50)$ & $1 / 1(100)$ & $0 / 2(0)$ & $76 / 209$ & (36.4) \\
\hline Ofloxacin(Of) & $63 / 178(35.4)$ & $1 / 6(16.7)$ & $0 / 3(0)$ & $2 / 2(100)$ & $0 / 4(0)$ & $4 / 11(36.4)$ & $1 / 2(50)$ & $1 / 1(100)$ & $0 / 2(0)$ & $72 / 209$ & (34.4) \\
\hline Amikacin(Ak) & $3 / 48(6.2)$ & $0 / 1(0)$ & NT & $0 / 2(0)$ & NT & $4 / 5(80)$ & $0 / 2(0)$ & $0 / 1(0)$ & NT & $7 / 59$ & (11.9) \\
\hline Chloramphenicol(C) & $13 / 48(27.1)$ & $1 / 1(100)$ & NT & $2 / 2(100)$ & NT & $5 / 5(100)$ & $0 / 2(0)$ & $0 / 1(0)$ & NT & $21 / 59$ & (35.6) \\
\hline Ceftazidime(Ca) & $48 / 48(100)$ & $1 / 1(100)$ & NT & $2 / 2(100)$ & NT & $5 / 5(100)$ & $1 / 2(50)$ & $0 / 1(0)$ & NT & $57 / 59$ & (96.6) \\
\hline Ceftriaxone(Ci) & $48 / 48(100)$ & $0 / 1(0)$ & NT & $2 / 2(100)$ & NT & $3 / 5(60)$ & $1 / 2(50)$ & $0 / 1(0)$ & NT & $54 / 59$ & (91.5) \\
\hline Gentamycin $(G)$ & 35/48(72.9) & $1 / 1(100)$ & NT & $2 / 2(100)$ & NT & $5 / 5(100)$ & $0 / 2(0)$ & $0 / 1(0)$ & NT & $43 / 59$ & (72.9) \\
\hline
\end{tabular}

The numbers within non-parentheses indicate the number of resistant isolates by total number isolates and the numbers within parentheses indicate the percent resistance

NT: not tested 
Table 3 Distribution of MDR isolates resistant to indicated class range of antibiotics

\begin{tabular}{lllllllll}
\hline Organism & $\begin{array}{l}3-4 \\
\text { classes }\end{array}$ & \multicolumn{3}{l}{$\begin{array}{l}\mathbf{5 - 6} \\
\text { classes }\end{array}$} & $\begin{array}{l}\text { 27 } \\
\text { classes }\end{array}$ & \multicolumn{2}{l}{ Total } \\
\hline & $\mathbf{n}$ & $\%$ & $\mathbf{n}$ & $\%$ & $\mathbf{n}$ & $\%$ & $\mathbf{n}$ & $\%$ \\
Acinetobacter spp. $(\mathrm{n}=2)$ & 1 & 50 & 0 & 0 & 0 & 0 & 1 & 50 \\
Citrobacter spp. $(\mathrm{n}=11)$ & 6 & 54.5 & 1 & 9.1 & 1 & 9.1 & 8 & 72.7 \\
CoNS* $(\mathrm{n}=6)$ & 1 & 16.7 & 2 & 33.3 & 0 & 0 & 3 & 50 \\
E. coli $(\mathrm{n}=178)$ & 54 & 30.3 & 13 & 7.3 & 1 & 0.6 & 68 & 38.2 \\
Enterobacter spp. $(\mathrm{n}=4)$ & 1 & 25 & 0 & 0 & 0 & 0 & 1 & 25 \\
K. oxytoca $(\mathrm{n}=2)$ & 1 & 50 & 0 & 0 & 0 & 0 & 1 & 50 \\
K. pneumoniae $(\mathrm{n}=4)$ & 1 & 25 & 0 & 0 & 0 & 0 & 1 & 25 \\
M. morganii $(\mathrm{n}=2)$ & 0 & 0 & 0 & 0 & 0 & 0 & 0 & 0 \\
P. mirabilis $(\mathrm{n}=3)$ & 0 & 0 & 0 & 0 & 0 & 0 & 0 & 0 \\
P. aeruginosa $(\mathrm{n}=2)$ & 0 & 0 & 2 & 100 & 0 & 0 & 2 & 100 \\
S. typhi $(\mathrm{n}=1)$ & 1 & 100 & & & 0 & 0 & 1 & 100 \\
S. aureus $(\mathrm{n}=1)$ & 0 & 0 & 0 & 0 & 1 & 100 & 1 & 100 \\
E. faecalis $(\mathrm{n}=3)$ & 2 & 66.7 & 1 & 33.3 & 0 & 0 & 3 & 100 \\
Total $(\mathrm{n}=219)$ & 68 & 31 & 19 & 8.7 & 3 & 1.4 & 90 & 41.1 \\
\hline
\end{tabular}

${ }^{*} \mathrm{CoNS}=$ coagulase-negative staphylococci

transconjugants showed high MIC values for the antibiotics tested, upto $\geq 512 \mu \mathrm{g} / \mathrm{ml}$ (ampicillin, chloramphenicol, cefixime, and trimethoprim) and $\geq 64 \mu \mathrm{g} / \mathrm{ml}$ (ciprofloxacin, norfloxacin and gentamycin) (Table 4).

\section{Discussion}

The present study provides the information about the distribution and the antibiotic resistance pattern of bacterial pathogens isolated from the UTI patients from Nepal. In addition, to our knowledge, this is the first report to indicate a possible plasmid-mediated transfer of multidrug resistance among MDR E. coli isolates from UTIs in Nepal. Our study showed that Enterobacteriaceae are predominant causative organisms to cause UTI, followed by Gram-positive cocci, a finding consistent with reports published elsewhere $[15,16]$. Among the Gram-negative bacteria, highest percents of resistance towards first-line antibiotics were found for amoxycillin (57.7\%), co-trimoxazole (53.6\%), and norfloxacin (36.4\%). However, overall amikacin and nitrofurantoin showed a least resistance, $11.9 \%$ and $13.4 \%$, respectively. Among Gram-positive pathogens, CoNS were found most predominant and were resistant to cephalexin (33.4\%), cloxacillin (33.4\%) and co-trimoxazole (33.4\%) in the first-line of antibiotics. Although most of the $S$. aureus and enterococci species were found resistant to $\beta$-lactam antibiotics, fortunately resistance towards vancomycin was not observed. These results are basically in agreement with other studies [15,17].

Our report, similar to previous reports, shows that $E$. coli is the predominant causative agent of UTIs with high rate of antibiotic resistance $[6,7,16,18]$. Out of the $178 E$. coli isolates, $55.6 \%$ showed resistance to amoxycillin, $54.4 \%$ to co-trimoxazole, $36.5 \%$ to norfloxacin and $35.9 \%$ to ciprofloxacin. Amoxycillin and co-trimoxazole resistance rates in our report were higher in comparison to other reports, hence empirical therapy with these antibiotics seems inadequate and should be avoided [6,18].

Among the antibiotics evaluated secondarily, amikacin was found most effective to all of the E. coli isolates tested. Our results show a substantial increase in the resistance to quinolones by $E$. coli isolates, an observation also reported by others $[12,16,19]$. Since nitrofurantoin has shown low overall E. coli and other isolates resistance rate in both hospitalized- and out-patients, it can be considered as the first-line therapy, a finding similar to other studies [12,20,21]. Similarly, overall resistance to aminoglycosides was comparatively low. This is consistent with previous studies of antimicrobial susceptibility in UTI infections. For examples, Aypak et al. showed the $6.1 \%$ resistance by E. coli [18], and Bean et al. showed the $6.7 \%$ resistance [20].

In our report, we found a high incidence of MDR UTIs in both hospitalized-patients (85\%) and outpatients $(36.7 \%)$, however the difference between two groups is significant. It gives the impression of extensive dissemination of MDR uropathogens in both community and hospital environment. The contributing factors for the appearance of such high bacterial antibiotic resistance in UTIs from both groups of patients may be numerous. One of them might be the injudicious use of antimicrobial agents, for example, self-medication, which is a common practice of antibiotic misuses in Nepal. In our study, we observed high incidence of UTI caused by MDR pathogens in male patients than female patients. It might be due to the reason that the incidence of UTIs among male patients is often associated with old age and/or using of mechanical devices, both of these factors have been found to contribute the multidrug resistance phenotype [22]. We observed high multidrug resistance rate in Enterobacteriaceae isolates as 7.3\% E. coli and $18.2 \%$ Citrobacter spp. showed antibiotic resistance to $>5-6$ classes (Table 3 ). In our report, the most prevalent MDR pattern shown by $E$. coli includes resistance to: amoxycillin, ciprofloxacin, cephotaxime, cefixime, co-trimoxazole, ofloxacin, norfloxacin, ceftazidime, gentamycin and ceftriaxone. Most of the MDR E. coli isolates showed high resistance rate to different classes of antibiotics. Our these findings are compatible with the reports from different parts of the world, including Nepal $[6,16,18,21,23]$. Our findings suggest that the antibiotic treatment options for UTIs caused by $E$. coli have severely impaired due to the resistance to commonly-used antibiotics, which might lead to the situation to rely only on certain antibiotics like fosfomycin, colistin and carbapenem. 
Table 4 Conjugational transfer of multidrug resistance phenotypes in E. coli

\begin{tabular}{|c|c|c|c|c|c|c|c|c|c|c|c|c|c|c|}
\hline \multirow{2}{*}{$\begin{array}{c}\text { Donor } \\
\begin{array}{c}\text { Resistance } \\
\text { pattern }\end{array}\end{array}$} & \multicolumn{6}{|c|}{ Transconjugant } & \multicolumn{7}{|c|}{$\begin{array}{l}{ }^{\mathrm{C}} \mathrm{MIC}(\mu \mathrm{g} / \mathrm{ml}) \text { of antibiotics towards donors and } \\
\text { transconjugants }\end{array}$} & \multirow[t]{2}{*}{$\begin{array}{l}{ }^{\text {a Conjugation }} \\
\text { frequency }\end{array}$} \\
\hline & $\begin{array}{l}\text { Plasmid } \\
\text { (kb) }\end{array}$ & $\begin{array}{l}{ }^{\mathrm{b}} \mathrm{ESBL} \\
\text { activity }\end{array}$ & $\begin{array}{l}\text { Resistance } \\
\text { pattern }\end{array}$ & $\begin{array}{l}\text { Plasmid } \\
\text { (kb) }\end{array}$ & $\begin{array}{l}{ }^{\mathrm{b}} \mathrm{ESBL} \\
\text { activity }\end{array}$ & & $\mathrm{Am}$ & C & $\mathrm{Cf}$ & Cfx & G & $\mathrm{Nx}$ & Co & \\
\hline \multirow[t]{2}{*}{$\begin{array}{c}\mathrm{Am}, \mathrm{Cf}, \mathrm{Ce}, \mathrm{Cfx}, \\
\mathrm{Co}, \mathrm{Of}, \mathrm{Nx} \\
\mathrm{Ca}, \mathrm{C}\end{array}$} & 32.5 & - & $\begin{array}{c}\text { Am, Cf, Cfx, } \\
\text { Co, Of, Nx }\end{array}$ & 32.5 & - & $\mathrm{D}$ & $>512$ & & $>256$ & $>512$ & & 128 & 512 & $0.3 \times 10^{-7}$ \\
\hline & & & & & & $\mathrm{T}$ & $>512$ & & 64 & $>512$ & & 64 & 512 & \\
\hline \multirow[t]{2}{*}{$\begin{array}{c}\mathrm{Am}, \mathrm{Cf}, \mathrm{Ce}, \mathrm{Cfx} \\
\mathrm{Co}, \mathrm{Of}, \mathrm{Nx} \\
\mathrm{Ca}, \mathrm{C}, \mathrm{G}, \mathrm{Ci}\end{array}$} & 32.5 & + & $\begin{array}{c}\text { Am, Cf, Cfx, } \\
\text { Co, Of, Nx }\end{array}$ & 32.5 & + & D & $>512$ & & $>256$ & $>512$ & & $>256$ & $>512$ & $0.6 \times 10^{-7}$ \\
\hline & & & & & & $\mathrm{T}$ & $>512$ & & 64 & 512 & & 64 & $>512$ & \\
\hline \multirow[t]{2}{*}{$\begin{array}{l}\mathrm{Am}, \mathrm{Cf}, \mathrm{Co}, \mathrm{Nx}, \\
\mathrm{Na}, \mathrm{Of}, \mathrm{Ca}, \mathrm{Ci}\end{array}$} & 32.5 & + & $\begin{array}{l}\text { Am, Cf, Cfx, } \\
\mathrm{Co}, \mathrm{Of}, \mathrm{Nx}\end{array}$ & 32.5 & + & D & $>512$ & & $>256$ & $>512$ & & $>256$ & $>512$ & $1.5 \times 10^{-7}$ \\
\hline & & & & & & $\mathrm{T}$ & $>512$ & & 128 & $>512$ & & 64 & 512 & \\
\hline \multirow[t]{2}{*}{$\begin{array}{c}\mathrm{Am}, \mathrm{Cf}, \mathrm{Ce}, \mathrm{Cfx}, \\
\mathrm{Co}, \mathrm{Of}, \mathrm{Nx} \\
\mathrm{Ca}, \mathrm{G}, \mathrm{Ci}\end{array}$} & 32.5 & - & $\begin{array}{l}\text { Am, Cf, Cfx, } \\
\mathrm{Co}, \mathrm{Of}, \mathrm{Nx}\end{array}$ & 32.5 & - & $D$ & 512 & & $>256$ & $>512$ & & $>256$ & $>512$ & $0.6 \times 10^{-7}$ \\
\hline & & & & & & $\mathrm{T}$ & 512 & & 64 & 512 & & 64 & 512 & \\
\hline \multirow[t]{2}{*}{$\begin{array}{c}\text { Am, Cf, Ce, Cfx, } \\
\text { Co, Of, Nx, } \\
\text { Ca, C, G, Ci }\end{array}$} & $32.5,4.7$ & + & $\begin{array}{l}\mathrm{Am}, \mathrm{Cf}, \mathrm{Cfx}_{1} \\
\mathrm{Co}, \mathrm{Of}, \mathrm{Nx} \\
\mathrm{C}, \mathrm{G}\end{array}$ & 32.5 & + & $D$ & $>512$ & 512 & $>256$ & $>512$ & $>64$ & $>256$ & $>512$ & $1.2 \times 10^{-7}$ \\
\hline & & & & & & $\mathrm{T}$ & $>512$ & 512 & 128 & 512 & $>64$ & 128 & $>512$ & \\
\hline \multirow{2}{*}{$\begin{array}{c}\text { Am, } \mathrm{Cf}, \mathrm{Ce}, \mathrm{Cfx} \\
\mathrm{Co}, \mathrm{Of}, \mathrm{Nx} \\
\mathrm{Ca}, \mathrm{G}, \mathrm{Ci}\end{array}$} & 51 & + & $\begin{array}{l}\text { Am, Cf, Cfx, } \\
\text { Co, Of, Nx }\end{array}$ & 51 & - & D & 512 & & $>128$ & 512 & & 128 & 512 & $0.5 \times 10^{-7}$ \\
\hline & & & & & & $\mathrm{T}$ & 256 & & 32 & 256 & & 32 & 512 & \\
\hline \multirow{2}{*}{$\begin{array}{c}\text { Am, } \mathrm{Cf}, \mathrm{Ce}, \mathrm{Cfx}, \\
\mathrm{Co}, \mathrm{Of}, \mathrm{Nx} \\
\mathrm{Ak}, \mathrm{Ca}, \mathrm{G}, \mathrm{Ci}\end{array}$} & 38 & + & $\begin{array}{l}\text { Am, Cf, Cfx, } \\
\text { Co, Of, Nx }\end{array}$ & 38 & + & D & $>512$ & & $>256$ & $>512$ & & $>256$ & $>512$ & $0.8 \times 10^{-7}$ \\
\hline & & & & & & $\mathrm{T}$ & $>512$ & & 64 & $>512$ & & 64 & $>512$ & \\
\hline \multirow[t]{2}{*}{$\begin{array}{c}\mathrm{Am}, \mathrm{Cf}, \mathrm{Co}, \mathrm{Nx} \\
\mathrm{Ca}, \mathrm{Ci}\end{array}$} & 38 & - & $\begin{array}{l}\text { Am, Cf, Cfx, } \\
\mathrm{Co}, \mathrm{Of}, \mathrm{Nx}\end{array}$ & 38 & - & D & 512 & & 128 & $>512$ & & 128 & 512 & $0.5 \times 10^{-7}$ \\
\hline & & & & & & $\mathrm{T}$ & 256 & & 64 & 256 & & 64 & 512 & \\
\hline \multirow{2}{*}{$\begin{array}{c}\mathrm{Am}, \mathrm{Cf}, \mathrm{Ce}, \mathrm{Cfx} \\
\mathrm{Co}, \mathrm{Of}, \mathrm{Nx} \\
\mathrm{C}, \mathrm{Ca}, \mathrm{G}, \mathrm{Ci}\end{array}$} & $32.5,6.5$ & + & $\begin{array}{l}\text { Am, Cf, Cfx, } \\
\mathrm{Co}, \mathrm{Of}, \mathrm{Nx}\end{array}$ & $32.5,6.5$ & + & D & 512 & & 128 & $>512$ & & 128 & $>512$ & $0.3 \times 10^{-7}$ \\
\hline & & & & & & $\mathrm{T}$ & 512 & & 64 & $>512$ & & 64 & $>512$ & \\
\hline \multirow{2}{*}{$\begin{array}{c}\mathrm{Am}, \mathrm{Cf}, \mathrm{Ce}, \mathrm{Cfx} \\
\mathrm{Co}, \mathrm{Of}, \mathrm{Nx} \\
\mathrm{Ca}, \mathrm{Ci}\end{array}$} & 32.5 & + & $\begin{array}{l}\text { Am, Cf, Cfx, } \\
\mathrm{Co}, \mathrm{Of}, \mathrm{Nx}\end{array}$ & 32.5 & + & D & $>512$ & & 128 & $>512$ & & 128 & $>512$ & $1.2 \times 10^{-7}$ \\
\hline & & & & & & $\mathrm{T}$ & $>512$ & & 64 & $>512$ & & 64 & 512 & \\
\hline
\end{tabular}

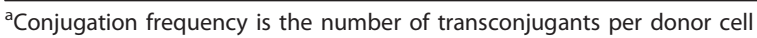

${ }^{\mathrm{b}} E S B L=$ extended-spectrum $\beta$-lactamase

${ }^{c} M I C=$ minimum inhibitory concentration of antibiotic at which visible growth of isolates were inhibited

Am-amoxycillin, Ce-cefotaxime, Cfx-cefixime, Cf-ciprofloxacin, Co-cotrimoxazole, Nf-nitrofurantoin, Nx-norfloxacin, Of-ofloxacin, Ak-amikacin, C-chloramphenicol, Ca-ceftazidime, Ci-ceftriaxone, G-gentamycin, D-donor, T-transconjugant

We observed high prevalence of ESBL production phenotypes (55.2\%) in a subset of MDR E. coli isolates. ESBL-producing isolates are often found to show coresistance to many classes of antibiotics [24]. This might be a reason of high multidrug resistance phenotypes among E.coli isolates in our study. Especially, the increased resistance observed to fluoroquinolone, aminopenicillin and cephalosporins are striking, because these antibiotics are first choice to treat UTI in Nepal. Our data, indicating the enormous bias to bulk MDR $E$. coli isolation, hint the possibility of emergence and spread of dominant UTI- causing MDR E. coli strain by mutation, in the locality. Although such possibility is contradictory to other reports, where non-E. coli isolates also share the major part of MDR UTI isolates [6,21]. The previous reports on uropathogens and their antimicrobial susceptibility pattern from different regions of Nepal also gives the impression of existence of such situation in Nepal [25-27]. In support, a study in Denmark indicated that the mutational events, not clonal 
spread, are mainly responsible for the higher incidence of UTI-causing MDR E. coli, due to the increased use of fluoroquinolone [28]. Further molecular study including large number of isolates from different geographical regions of Nepal are needed to confirm the possibility of selection and spread of dominant MDR E. coli strain in the locality.

We found a wide range of plasmids of size $2 \mathrm{~kb}$ to 51 $\mathrm{kb}$, as similar to others, in selected E. coli isolates. [29]. However, we did not find very large plasmids, as evidenced by other [30]. In our conjugation study, most of the transconjugants showed the MDR phenotypes and ESBL-producing phenotypes similar to donors. In our report, transconjugants having large mobilizable plasmids of size $32.5 \mathrm{~kb}, 38 \mathrm{~kb}$ and $51 \mathrm{~kb}$ were found resistant to at least amoxycillin, ciprofloxacin, cotrimoxazole, ofloxacin and norfloxacin (Table 4). Our these findings, similar to others, suggest the possibility of existence of plasmid-mediated broad-spectum multidrug resistance in uropathogens [31-34]. Additionally, we also observed the transfer of comparably small plasmids along with large plasmids by conjugation. The conjugation frequency of the MDR E. coli strains ranges from $0.3 \times 10^{-}$ 7 to $1.5 \times 10^{-7}$. Similar to this, the conjugation frequency of $10^{-7}$ was also found with transfer of five antibiotic resistance patterns in E. coli $\mathrm{AB} 1157$ recipient strain [8]. Similar to donors, the MIC of the tested antibiotics towards the transconjugants was also high, except fluoroquinolones. The high MIC values shown by donors as well as recipient $E$. coli strain suggest the existence of high levels of transferable multidrug resistance in uropathogens. However, the transfer of high level fluoroquinolone resistance was not observed substantially by conjugation. This finding is consistent with other reports [35,36]. Such high levels of multidrug resistance among uropathogens have also been reported in other country $[28,37]$. Altogether, our findings suggest that there might be the transfer of antibiotic resistance genes by conjugation often en bloc in self-transferable or mobilizable plasmids, which might be responsible for the appearance of high multi drug resistance among bacterial uropathogens. Further studies involving molecular typing of antibiotic-resistant genes in plasmids are required to determine such possibility.

\section{Conclusion}

We observed the high prevalence of multidrug resistance among bacterial uropathogens. Particularly, rate of resistance to amoxycillin, co-trimoxazole, flouroquinolones and third-generation cephalosporins were higher and these antibiotics should be avoided for empirical-based therapy of UTIs. In such cases, empirical treatment with nitrofurantoin and amikacin might provide much better antibiotic coverage. In addition, we found that the MDR
E. coli isolates causing UTIs are capable of transferring MDR phenotypes with concomitant transfer of ESBL phenotypes to E. coli HB101 strain via conjugation. Altogether, our findings indicate the urgency to re-evaluate the first and second line of drugs for the antimicrobial therapy of UTIs. Regular national wise surveillance of multidrug resistance seems necessary step to combat the UTIs caused by MDR bacterial pathogens.

\section{Acknowledgements}

We are very grateful to all of the enrolled patients for their co-operation and the staff at Microbiology department, Kathmandu Model Hospital for their support and help during this work.

\section{Author details}

${ }^{1}$ Central Department of Microbiology, Tribhuvan University, Kirtipur, Kathmandu, Nepal. ${ }^{2}$ Department of Microbiology, Faculty of Science, Mahidol University, Bangkok, Thailand. ${ }^{3}$ Kathmandu Model Hospital, Kathmandu, Nepal.

\section{Authors' contributions}

PB has collected the sample and characterized bacterial isolates from UTI patients with the collaboration of SN. He also performed the antibiotic susceptibility testing and ESBL test with the help of SN. PB, BPM and KRG involved in the plasmid extraction and the conjugation study. BS and BL involved in study design. All authors have read the final version of manuscript and approved its finding for publication.

\section{Competing interests}

The authors declare that they have no competing interests.

Received: 9 November 2011 Accepted: 19 January 2012 Published: 19 January 2012

\section{References}

1. Wagenlehner FM, Naber KG: Treatment of bacterial urinary tract infections: presence and future. Eur Urol 2006, 49(2):235-244.

2. Gupta K: Addressing antibiotic resistance. Am J Med 2002, 113(Suppl 1A): S29-S34.

3. Giamarellou H: Multidrug-resistant Gram-negative bacteria: how to treat and for how long. Int J Antimicrob Agents 2010, 36(Suppl 2):S50-S54.

4. Hammer DA, Dongol S, Anderson TP, Wong JS, Werno AM, Murdoch DR: High prevalence of extended-spectrum beta-lactamase-producing Enterobacteriaceae in Nepal. Int J Antimicrob Agents 2007, 30(5):471-472.

5. Chakupurakal R, Ahmed M, Sobithadevi DN, Chinnappan S, Reynolds T: Urinary tract pathogens and resistance pattern. J Clin Pathol 2010, 63(7):652-654.

6. Karlowsky JA, Lagace-Wiens PR, Simner PJ, DeCorby MR, Adam HJ, Walkty A, Hoban DJ, Zhanel GG: Antimicrobial resistance in urinary tract pathogens in Canada from 2007 to 2009: CANWARD surveillance study. Antimicrob Agents Chemother 2011, 55(7):3169-3175.

7. Farajnia S, Alikhani MY, Ghotaslou R, Naghili B, Nakhlband A: Causative agents and antimicrobial susceptibilities of urinary tract infections in the northwest of Iran. Int J Infect Dis 2009, 13(2):140-144.

8. Vaidya VK: Horizontal transfer of antimicrobial resistance by extendedspectrum beta lactamase-producing Enterobacteriaceae. J Lab Physicians 2011, 3(1):37-42.

9. Harley JP, Prescott LM: Laboratory exercises in microbiology. 5 edition. McGraw-Hill Publishers; 2002, 37-237.

10. Clinical and Laboratory Standards Institute: Performance standards for antimicrobial susceptibility testing. sixteenth informational supplement document M100-S16 Wayne, PA: Clinical and Laboratory Standards Institute; 2006.

11. Sahm DF, Thornsberry C, Mayfield DC, Jones ME, Karlowsky JA: Multidrugresistant urinary tract isolates of Escherichia coli: prevalence and patient demographics in the United States in 2000. Antimicrob Agents Chemother 2001, 45(5):1402-1406. 
12. Simner PJ, Zhanel GG, Pitout J, Tailor F, McCracken M, Mulvey MR, LagaceWiens PR, Adam HJ, Hoban DJ: Prevalence and characterization of extended-spectrum beta-lactamase- and AmpC beta-lactamaseproducing Escherichia coli: results of the CANWARD 2007-2009 study. Diagn Microbiol Infect Dis 2011, 69(3):326-334.

13. Clinical and Laboratory Standards Institute: Methods for dilution antimicrobial susceptibility tests for bacteria that grows aerobically. Seventh edition. Wayne, PA: Clinical and Laboratory Standards Institute; 2006.

14. Clinical and Laboratory Standards Institute: Performance standards for antimicrobial susceptibility testing. Eighteenth informational supplement document M100-S18 Wayne, PA: Clinical and Laboratory Standards Institute; 2008.

15. Zhanel GG, Karlowsky JA, Harding GK, Carrie A, Mazzulli T, Low DE, Hoban DJ: A Canadian national surveillance study of urinary tract isolates from outpatients: comparison of the activities of trimethoprimsulfamethoxazole, ampicillin, mecillinam, nitrofurantoin, and ciprofloxacin. The Canadian urinary isolate study group. Antimicrob Agents Chemother 2000, 44(4):1089-1092.

16. Akram M, Shahid M, Khan AU: Etiology and antibiotic resistance patterns of community-acquired urinary tract infections in J N M C Hospital Aligarh. India Ann Clin Microbiol Antimicrob 2007, 6:4.

17. Zhanel GG, DeCorby M, Laing N, Weshnoweski B, Vashisht R, Tailor F, Nichol KA, Wierzbowski A, Baudry PJ, Karlowsky JA, et al: Antimicrobialresistant pathogens in intensive care units in Canada: results of the Canadian National Intensive Care Unit (CAN-ICU) study, 2005-2006. Antimicrob Agents Chemother 2008, 52(4):1430-1437.

18. Aypak C, Altunsoy A, Duzgun N: Empiric antibiotic therapy in acute uncomplicated urinary tract infections and fluoroquinolone resistance: a prospective observational study. Ann Clin Microbiol Antimicrob 2009, 8:27.

19. Meier S, Weber R, Zbinden R, Ruef C, Hasse B: Extended-spectrum betalactamase-producing Gram-negative pathogens in community-acquired urinary tract infections: an increasing challenge for antimicrobial therapy. Infection 2011, 39(4):333-340

20. Bean DC, Krahe D, Wareham DW: Antimicrobial resistance in community and nosocomial Escherichia coli urinary tract isolates, London 2005-2006. Ann Clin Microbiol Antimicrob 2008, 7:13.

21. Matute AJ, Hak E, Schurink CA, McArthur A, Alonso E, Paniagua M, Van Asbeck E, Roskott AM, Froeling F, Rozenberg-Arska M, et al: Resistance of uropathogens in symptomatic urinary tract infections in Leon, Nicaragua. Int J Antimicrob Agents 2004, 23(5):506-509.

22. Wright SW, Wrenn KD, Haynes M, Haas DW: Prevalence and risk factors for multidrug resistant uropathogens in ED patients. Am J Emerg Med 2000, 18(2):143-146.

23. Muvunyi CM, Masaisa F, Bayingana C, Mutesa L, Musemakweri A, Muhirwa G, Claeys GW: Decreased susceptibility to commonly used antimicrobial agents in bacterial pathogens isolated from urinary tract infections in Rwanda: need for new antimicrobial guidelines. AmJTrop Med Hyg 2011, 84(6):923-928.

24. Pitout JD, Laupland KB: Extended-spectrum beta-lactamase-producing Enterobacteriaceae: an emerging public-health concern. Lancet Infect Dis 2008, 8(3):159-166.

25. Rai GK, Upreti HC, Rai SK, Shah KP, Shrestha RM: Causative agents of urinary tract infections in children and their antibiotic sensitivity pattern: a hospital based study. Nepal Med Coll J 2008, 10(2):86-90.

26. Acharya A, Gautam R, Subedee L: Uropathogens and their antimicrobial susceptibility pattern in Bharatpur, Nepal. Nepal Med Coll J 2011, 13(1):30-33.

27. Kumari N, Ghimire G, Magar JK, Mohapatra TM, Rai A: Antibiogram pattern of isolates from UTI cases in Eastern part of Nepal. Nepal Med Coll J 2005, 7(2):116-118.

28. Christiansen N, Nielsen L, Jakobsen L, Stegger M, Hansen LH, FrimodtMoller N: Fluoroquinolone resistance mechanisms in urinary tract pathogenic Escherichia coli isolated during rapidly increasing fluoroquinolone consumption in a low-use Country. Microb Drug Resist 2011, 17(3):395-406.

29. Danbara H, Komase K, Kirii Y, Shinohara M, Arita H, Makino S, Yoshikawa M: Analysis of the plasmids of Escherichia coli O148: $\mathrm{H} 28$ from travellers with diarrhea. Microb Pathog 1987, 3(4):269-278.

30. Schmitt J, Jacobs E, Schmidt H: Molecular characterization of extendedspectrum beta-lactamases in Enterobacteriaceae from patients of two hospitals in Saxony, Germany. J Med Microbiol 2007, 56(Pt 2):241-249.
31. Benacer D, Thong KL, Watanabe H, Puthucheary SD: Characterization of drug resistant Salmonella enterica serotype Typhimurium by antibiograms, plasmids, integrons, resistance genes and PFGE. J Microbiol Biotechnol 2010, 20(6):1042-1052.

32. Robicsek A, Jacoby GA, Hooper DC: The worldwide emergence of plasmid-mediated quinolone resistance. Lancet Infect Dis 2006, 6(10):629-640.

33. Bennett PM: Plasmid encoded antibiotic resistance: acquisition and transfer of antibiotic resistance genes in bacteria. Br J Pharmacol 2008, 153(Suppl 1):S347-S357.

34. Shears $P$, Suliman $G$, Hart CA: Occurrence of multiple antibiotic resistance and $\mathrm{R}$ plasmids in Enterobacteriaceae isolated from children in the Sudan. Epidemiol Infect 1988, 100(1):73-81.

35. Shin JH, Jung HJ, Lee JY, Kim HR, Lee JN, Chang CL: High rates of plasmidmediated quinolone resistance QnrB variants among ciprofloxacinresistant Escherichia coli and Klebsiella pneumoniae from urinary tract infections in Korea. Microb Drug Resist 2008, 14(3):221-226.

36. Yang $\mathrm{H}$, Chen $\mathrm{H}$, Yang $\mathrm{Q}$, Chen $\mathrm{M}$, Wang $\mathrm{H}$ : High prevalence of plasmidmediated quinolone resistance genes qnr and aac $\left(6^{\prime}\right)-\mathrm{lb}-\mathrm{cr}$ in clinical isolates of Enterobacteriaceae from nine teaching hospitals in China. Antimicrob Agents Chemother 2008, 52(12):4268-4273.

37. Ogbolu DO, Daini OA, Ogunledun A, Alli AO, Webber MA: High levels of multidrug resistance in clinical isolates of Gram-negative pathogens from Nigeria. Int J Antimicrob Agents 2011, 37(1):62-66.

doi:10.1186/1756-0500-5-38

Cite this article as: Baral et al:: High prevalence of multidrug resistance in bacterial uropathogens from Kathmandu, Nepal. BMC Research Notes 2012 5:38.

\section{Submit your next manuscript to BioMed Central and take full advantage of:}

- Convenient online submission

- Thorough peer review

- No space constraints or color figure charges

- Immediate publication on acceptance

- Inclusion in PubMed, CAS, Scopus and Google Scholar

- Research which is freely available for redistribution

Submit your manuscript at www.biomedcentral.com/submit
C Biomed Central 